\title{
部品内蔵基板の歩みと今後の課題
}

\author{
見山 克己*
}

\section{Circumstances of Developing Device Embedded Substrate and Its Future Subjects}

\author{
Katsumi MIYAMA*
}

* 北海道科学大学工学部機械工学科（ $\overline{\mathbf{T}}$ 006-8585 札幌市手稲区前田 7 条 15 丁目 4-1)

* Faculty of Engineering, Department of Mechanical Engineering, Hokkaido University of Science (7-15, Maeda Teine-ku, Sapporo, Hokkaido 006-8585)

\section{1. はじめに}

部品内蔵基板は, 高密度配線の実現や電気的・熱的特 性，またデバイス実装部接続信頼性の向上が見込める有望 な技術である。三次元配置による設計自由度増大に伴い大 きなダウンサイジング効果が見込めるとともに, 部品間の 配線長短縮により高周波特性の改善, ノイズ低減などの電 気特性改善効果が期待される。2000 年代からデバイスを内 蔵したプリント配線板の実用化が相次ぎ 1),2), 当初は民生用 のモジュール基板に主な適用事例が見られたが，現在では スマートフォンメイン基板や車載機器用の適用事例が見ら れる様になってきた ${ }^{3)}$ 。

しかしながら部品内蔵基板そのものの概念は古く，また 一部の限定された用途においては基板内部に素子を作り込 む手法により部品（素子）内蔵基板が用いられてきた。そ れらを第 1 世代とすれば, 完成されたデバイスを埋め込む 手法は第 2 世代以降と位置づけられる。その中でも, 既存 の表面実装デバイスを内蔵した第 2 世代, その後に, 内蔵 用に開発された低背部品を埋め込み, かつめっき接続な ど，新たな接続手法を用いた第 3 世代に分類されると考え ている。本稿では, これら部品内蔵基板のこれまでの歩み を振り返ると共に, 今後より一層適用を拡大していくため の課題について考察してみたい。

\section{2. 基板内への素子作り込み 一第 1 世代一}

プリント配線板は, 絶縁材料と金属銅導体を用いて構成 されており，誤解を恐れずにいえば単なる配線部材であ り，そこに「配線」以上の機能は付与されない。しかしな がらそのプリント配線板内に受動素子機能を何らかの手段 により作り込む素子内蔵は, 実は比較的古い時期から実用 化されている。例えば, 抵抗素子としてはカーボンペース トを用いて配線パターン間に印刷抵抗を形成する手法や ${ }^{4)}$, $\mathrm{Ni}$ 系薄膜を利用して抵抗体を形成する手法が実用化されて いる ${ }^{5)}$ 。 $\mathrm{Ni}$ 系薄膜を利用する手法は, 米国オメガ・テクノ ロジー社により開発された商品名オメガ・プライと呼ばれ
る銅箔を使用する手法が最初である。これは電解銅箔の マット面側に Ni-P 合金の薄膜が形成されており，一般的な 配線板製造プロセスである銅箔積層および銅箔エッチング によるパターン形成を行った後に, 再度フォトリソにより Ni-P 薄膜をエッチングすることにより所定の抵抗パターン を得るものである。これは $\mathrm{Ni}$ 薄膜の厚みや $\mathrm{P}$ 組成により シート抵抗值を可変できること, プロセスが配線板製造工 程と親和性が高いことなどのメリットを有する。また, カーボンペーストを用いた手法もスクリーン印刷と乾燥に より形成できるため, これも配線板製造工程と親和性が高 w。

しかしながら, これらの手法は一部の限定的な利用にと どまった。カーボンペースト印刷抵抗は印刷精度に抵抗值 ばらつきが支配されること，また抵抗体のマトリックスが 樹脂材料であるため, 温湿度に対する特性変化が大きいこ とがデメリットであった。ニッケル系薄膜は特性変化の点 では印刷抵抗より安定しているものの, 金属材料であるが 故にシート抵抗值が最大でも $250 \Omega / \mathrm{sq}$ 程度にとどまるた め, 適用範囲が限定された。一方コンデンサは，米国の配 線板メーカであるZycon 社（HADOC 社を経て Sanmina-SCI 社）が, ガラスエポキシ絶縁材（以下「ガラエポ」）を誘電 体として層間にコンデンサを形成する BC (Buried Capacitor)

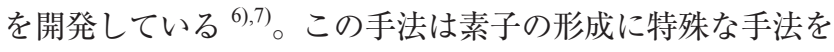
必要としないメリットを有するが, ガラエポの誘電率は一 般的に 4 前後と低いため, 必要な静電容量を得るためには 大面積パターンが必要となる。このためルータ・サーバな どの大型基板に適用がとどまっている。その後米国では 1999～2002 年に部品内蔵技術に関わるコンソーシアムが形 成され, 内蔵素子のための材料開発・評価を行った。この コンソーシアムで開発された材料による素子形成の一例を 紹介する ${ }^{8)}$ 。この技術は, 素子材料としてセラミック系の 無機材料を用いることにより，それまでの課題であった温 湿度による特性ドリフトの改善, 高いシート抵抗值や高い 比誘電率による高静電容量の実現を狙ったものである。

抵抗素子の製造プロセスとしては，はじめに銅箔の粗化 


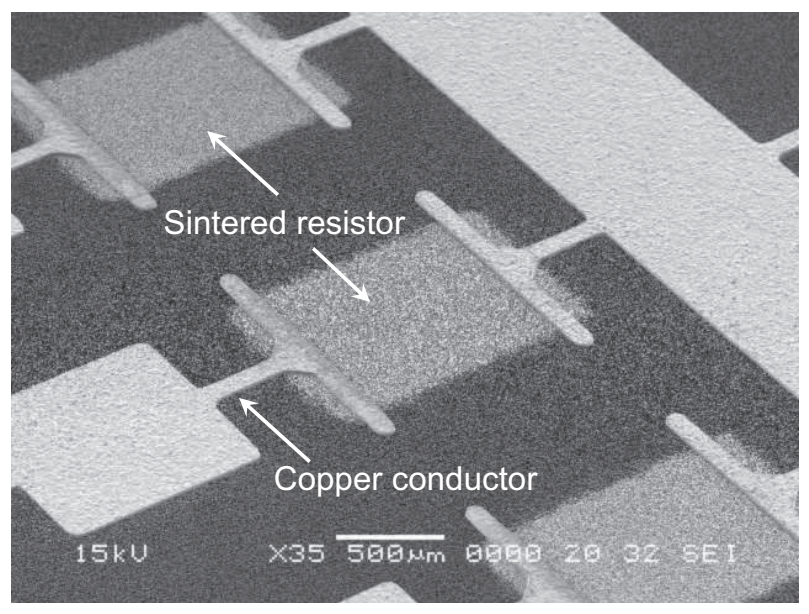

Fig. 1 Appearance of sintered resistor and electrode

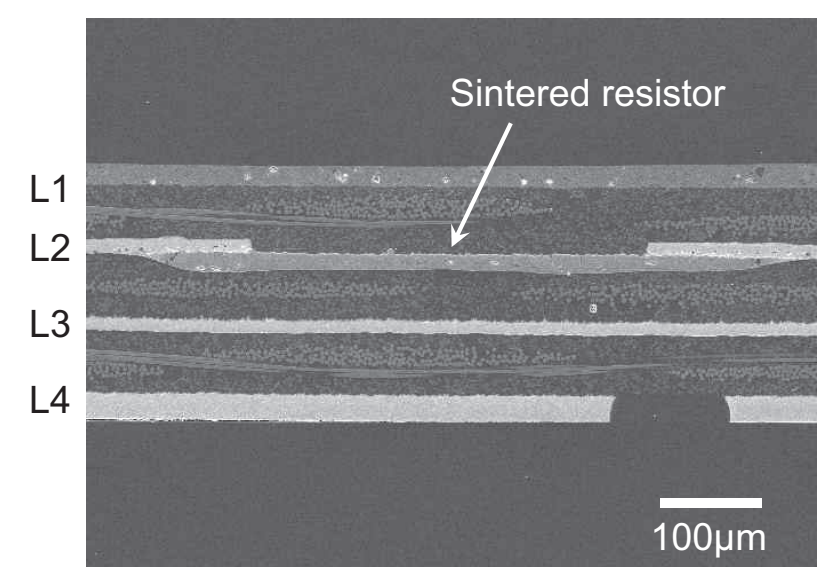

Fig. 2 Cross section of embedded resistor

面に抵抗ペーストをスクリーン印刷にて所定の形状に形成 する。溶剂揮発のため乾燥処理を行った後, 素子焼結のた め $900^{\circ} \mathrm{C}, \mathrm{N}_{2}$ 䨌囲気で焼成を行う。焼成後のワークは, プ リプレグを介して内層板に積層プレスされる。積層プレス 後のワークは, 一般的な工法でパターン形成を行う。一例 としてパターン形成後の状態を Fig. 1 に示す。 $1 \mathrm{~mm} \times 1 \mathrm{~mm}$ の抵抗素子が得られる様, 抵抗膜と電極パターンを形成し た。

コンデンサの形成プロセスも基本的な流れは抵抗と同様 である。ただし，コンデンサの場合は誘電体を挟んで銅箔 と対向する電極形成が必要である。このため, 誘電体を銅 䇴上に印刷した後, 対向電極となる銅ペーストを誘電体に 重ねて印刷する。このワークを抵抗と同様の条件で焼成を 行い, 誘電体と銅ペーストを同時焼成する。

4 層の全層をビルドアップ工法で製造したプリント配線 板に, 焼成抵抗素子を内蔵した事例の断面写真を Fig. 2 に 示す。全層に公称厚み $60 \mu \mathrm{m}$ のハロゲンフリーFR-4を用 い,この配線板の第 2 層に抵抗を配置した。ソルダーレジ ストを含めた総板厚は $0.33 \mathrm{~mm}$ であり, 素子内蔵無しの場 合の板厚と有意差はなく, 素子を内蔵しても板厚に影響が

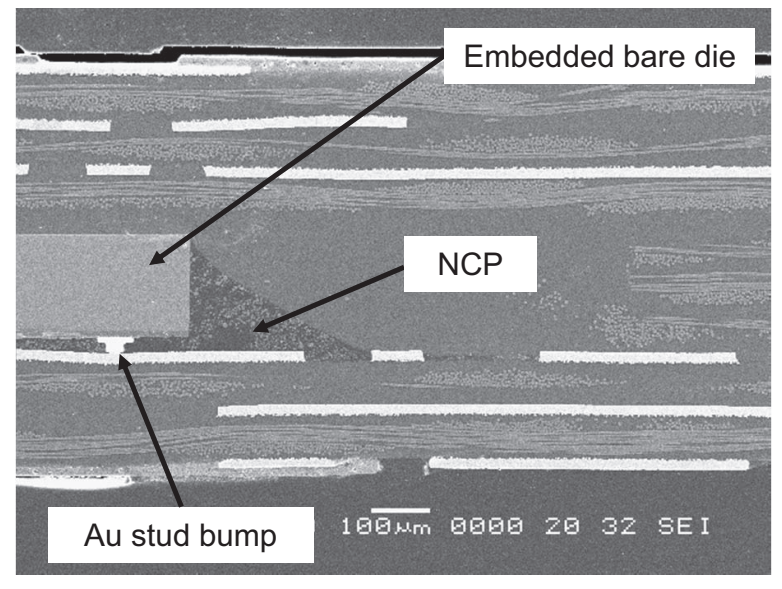

Fig. 3 Cross section of embedded bare die

ないことが確認できた。

\section{LSI 内蔵 一第 2 世代一}

2000 年代に入り, 携帯電話の多機能化とダウンサイジン グ要求のもと, 配線板の高密度化・面積縮小の要求が大き くなってきた。この流れの中で, 表面実装部品の中で専有 面積の大きい能動部品を内蔵することによる大幅な基板面 積削減に各社が目を向け始めた。これの事例のうち, ベア チップを内蔵して通信モジュール基板の面積削減に成功し た事例を紹介する 9)。内蔵するデバイスは，完成モジュー ル部品低背化を目的として極力薄型の部品を用いることと し， $0.15 \mathrm{~mm}$ 厚までバックグラインドされたベアチップを 用いた。実装方法はベアチップをフェースダウンとするフ リップチップ工法とし，Au ワイヤースタッドバンプを用い る熱圧着工法を採用した。内蔵したベアチップ部分の断面 を Fig. 3 に示す。なお，実装面は配線板内層であるため， 積層前処理（化学的粗化処理）を行う関係上 $\mathrm{Au}$ めっきは 実施していない。したがって Au スタッドバンプと基板電 極との接合界面に治金的接合が期待できないため，使用環 境下において界面に常に圧縮応力が発生していることが必 要である。このため, チップと基板間を充填する NCP (Non-Conductive Paste) の物性值最適化を行うことにより求 められる信頼性を確保した。

この技術を通信用モジュール基板に適用し，面積削減を 試みた。この製品はLSIを 2 個使用する設計になっており， このうちの 1 つのベアチップを内蔵した。これにより，面 積比でモジュール基板サイズを内蔵前の $36.5 \%$ まで縮小す ることに成功した。

\section{4. 低背受動部品の埋め込みと接続方法の多様化 一第 3 世代一}

前述第 2 世代の部品内蔵では, 基板面積削減効果の大き さから能動部品内蔵が先行したが, これに若干遅れたもの のチップ受動部品を内層にはんだ実装して埋め込む手法も 


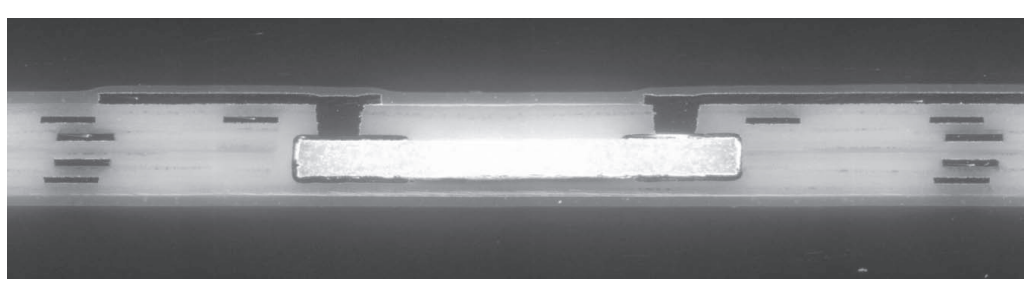

Fig. 4 Example of passive device embedding by copper via connection ${ }^{11)}$

実用化が始まった ${ }^{10)}$ 。これにより, 能動・受動部品を混載 する内蔵に道が開けた。しかしながら, チップ受動部品の 内蔵については下記の課題に直面していた。

1) 部品高さによる基板薄板化制約

表面実装用のチップ部品は, 2000 年代前半, 主流 は 1005 サイズおよび 0603 サイズであった。この場 合, 部品高さが $0.3 \mathrm{~mm}$ 程度あるため, 内蔵基板の薄 板化に対する制約となる。

2）表面実装時のはんだ再溶融

内蔵実装にはんだを用いた場合, 表面実装リフロー 時に基板内部ではんだが再溶融する可能性が高い。こ の場合，はんだが液相となることに伴う体積膨張を生 じるため，層間デラミネーションを誘発することが予 想される。さらには, 層間デラミネーション発生部位 にはんだフラッシュが発生することにより短絡不良に もつながる。

3) 内層板への実装ハンドリング

配線板の薄板化が求められる一方で, 配線密度上昇 により配線板層数は増える傾向にある。この相反する 要求を満たすためには, 層間絶縁厚を減少させること になる。このため内層板は導体込み $50 \mu \mathrm{m}$ 程度の板 厚となるケースがあり，かつ工程に合わせたワークパ ネルサイズの大きさであるので，これにリフロー実装 を行うことには多くの困難を伴う。

チップ部品の低背化はチップ部品メーカ各社の開発努力 により, 現状では高さ $0.15 \mathrm{~mm}$ のチップ部品が提供されて いる。これにより内蔵基板薄板化に対する障害は大きく減 少した。またはんだ再溶融の課題に対しては, 表面実装の 際に不具合を生じない接合材料を用いることにより問題を 回避している。また内層板への実装ハンドリングに際して は，現実的にはリフロー工程に制約が多い。このため，は んだ系材料を用いずにめっきビアにより部品端子と配線板 導体を直接接続する手法が実用化されてきた。これは内層 板や銅箔にチップ部品をマウントして埋め込み, 部品の外 部電極端子に直接レーザビアなどで接続を行うものであ る。この一例を Fig. 4 に示す ${ }^{11)}$ 。従来のチップ部品外部電 極は $\mathrm{Sn}$ めっぎ主流であったが, ビアのめっきは $\mathrm{Cu}$ であ るので, 内蔵部品の場合は外部電極めっきが $\mathrm{Cu}$ であるこ とが望ましい。これについてもチップ部品メーカ各社の前 向きな取り組みにより, $\mathrm{Cu}$ めっき電極品が安定供給される
に至っている。

今後は，はんだ接続による手法とめっき接続による手法 がアプリケーションによって使い分けられ，技術として共 存していくことになるであろう。

\section{5. 直面する課題}

これまで述べてきたように，部品内蔵基板は多数の実用 化事例があり，また適用アプリケーションによってはんだ 接続・めっき接続を使い分けることができる要素技術も確 立されてきた。しかしながら 2000 年代初頭に期待されたほ ど適用が広がっているとは言いがたい。部品内蔵基板が直 面する課題について，これまで解決が図られたものも含め て考察してみたい。

まず第一に，新しい技術であるにもかかわらず用語・評 価方法を含めた技術標準・規格が存在しなかったことであ る。これは国際規格も存在しなかったため, 裏返せば日本 提案を国際規格とすることにより，日本がイニシアティヴ をとる可能性が高いことを意味する。JPCA（日本電子回路 工業会）内に設置された部品内蔵基板規格委員会の尽力に より，2008 年に部品内蔵配線板規格 JPCA-EB01 が発行さ れ，2013 年には第 6 版を数えるとともに，2014 年度中に IEC 国際規格として成立する見込みである。これについて は本特集号の中で福岡大学友景教授の解説記事に詳しいの で, そちらを参照されたい。次に, 部品内蔵基板における 設計上の課題が挙げられる。例えば, 部品内蔵基板の設計 に際しては, 物性の異なる異種材料が埋め込まれているこ とによる熱変形を考慮しなければならない。一般にリジッ ド基板の絶縁材料として用いられるガラエポは, 少なくと も $\mathrm{X}$ 方向, $\mathrm{Y}$ 方向の面内方向熱膨張は $\mathrm{Cu}$ に近く設計され ている。しかしながら部品内蔵で埋め込まれるデバイス は, その機械的物性において配線板材料との整合は考慮さ れていない。このため, 設計段階においてその物性差を十 分考慮する必要があり，そのためにはCAEツールを用いた 事前シミュレーションがきわめて有用である。すなわち, シミュレーションの活用によりトライ\&エラーの回数を削 減することで，試作期間の短縮を図ることが可能である。 本稿では, ベアチップ内蔵基板の熱変形をシミュレーショ ン計算し，実際の変形挙動と比較した事例を示す ${ }^{12)}$ 。

モデルとして，Fig. 5 に示すべアチップ内蔵基板を用い た。基材厚みは $0.1 \mathrm{~mm}$ と $0.3 \mathrm{~mm} の 2$ 種類, 配線板の導体 


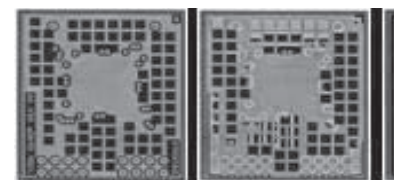

L1

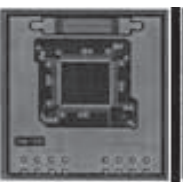

L3

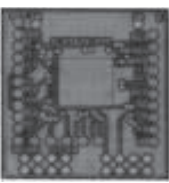

L4

(a) Solid pattern

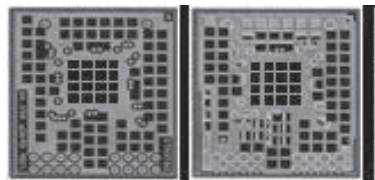

L1

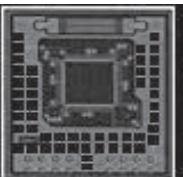

L3

(b) Mesh pattern

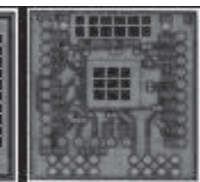

L4

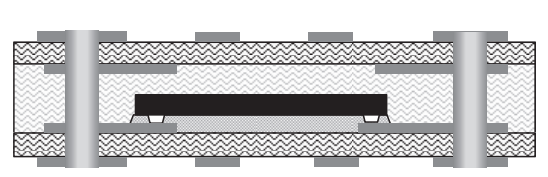

(c) $0.1 \mathrm{mmt}$ core

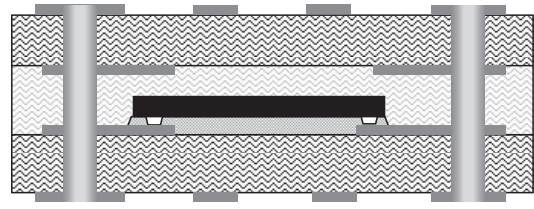

(d) $0.3 \mathrm{mmt}$ core

Fig. 5 Simulated bare die embedded substrate

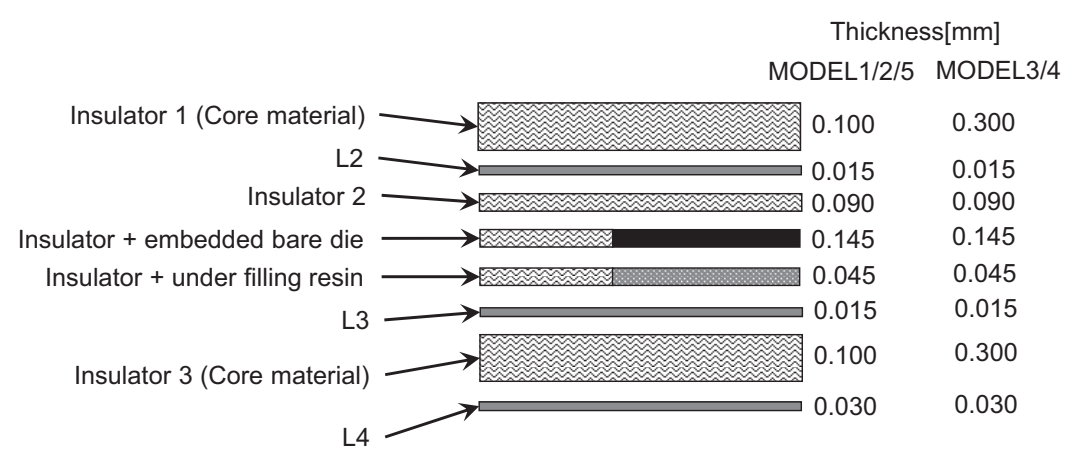

(b) Layer structure

Fig. 6 FEM (finite element method) model

は銅べ夕を使用したパターンとベタをメッシュ化したパ ターンの 2 種類を想定し，これらの組み合わせで計 4 種類 の解析を実施した。

また内蔵するチップは $0.1 \mathrm{~mm}$ 厚で $10 \mathrm{~mm}$ 角とし, 下面 にはアンダーフィル樹脂が充填された構造とした。解析モ デルの断面構造を Fig. 6 に示す。実際の配線板は製造後の 初期状態で多少の変形や残留応力を内在するが, 本報の解 析においては室温で応力・歪みがゼロと仮定して初期温度 $25^{\circ} \mathrm{C}$ から $250^{\circ} \mathrm{C}$ まで加熱した際の熱変形挙動を求めた。解 析には ADINA8.6（米ADINA 社製）を用い, 非線形の熱弾 性解析とした。

解析結果の一例を Fig. 7 に示す。何れもべアチップ内蔵 部は中心部が凸形状に変形する傾向を示した。その周囲は 部位により変形挙動に差がみられ, 導体パターンの形状 · 粗密の影響があると推察された。Model1・2 はコア厚みが $0.1 \mathrm{~mm}$, Model3・4 はコア厚み $0.3 \mathrm{~mm}$ である。基板変形 量として, 厚み方向最大変位を求めた。これらを比較する
と Model2 の変形量が突出して大きく 4 モデル中最大の変 形量 $108 \mu \mathrm{m}$ であった。なお他のモデルは 46 $60 \mu \mathrm{m}$ の範 囲であった。この結果から, 基材剛性と内層導体層の形状 が配線板の熱変形に大きく影響することがわかった。解析 した 4 モデルに相当する基板を実際に製作してリフロー耐 熱試験を実施したところ，Model2 に相当する構造にのみべ アチップ下でのふくれ発生が認められ，計算された熱変形 量と害基板での膨れ発生状況は同様の傾向を示した。

このため, 内層の導体パターンを修正することにより変 形量をさらに低減することを検討した。導体パターンの修 正を Fig. 8(a) に示す。調整した箇所は, Model1・2で変位 が変曲点を有する凹凸部である。まず，Model1 の導体パ ターンを基に，L2 の残銅率調整を実施した。またべア実装 面の L3 では当初ベアチップ下の銅䇴は除去してあるが, この部分に銅べ夕を配置した。これらの変更を施したもの を Model5 とし, 同様に熱変形解析を行った結果を Fig. 8(b) に示す。熱変形量は $37 \mu \mathrm{m}$ と計算され，大幅に変形量を抑 
Max. displacement:0.060mm

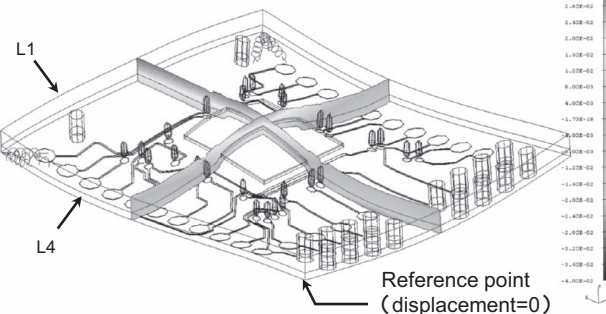

(a) MODEL1 (Core0.1 mm / Mesh pattern)
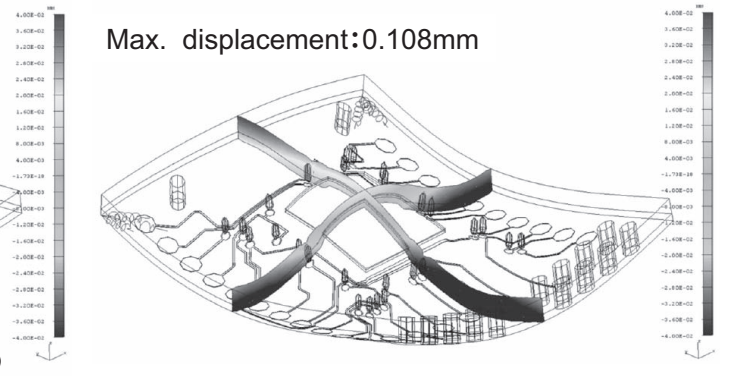

(b) MODEL2 (Core0.1 $\mathrm{mm}$ / Solid pattern)

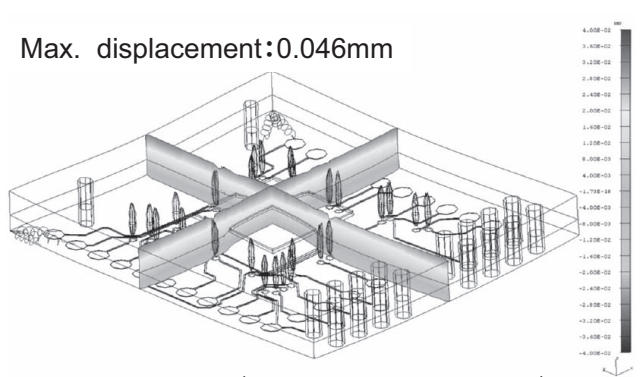

(c) MODEL3 (Core0.3mm / Mesh pattern)

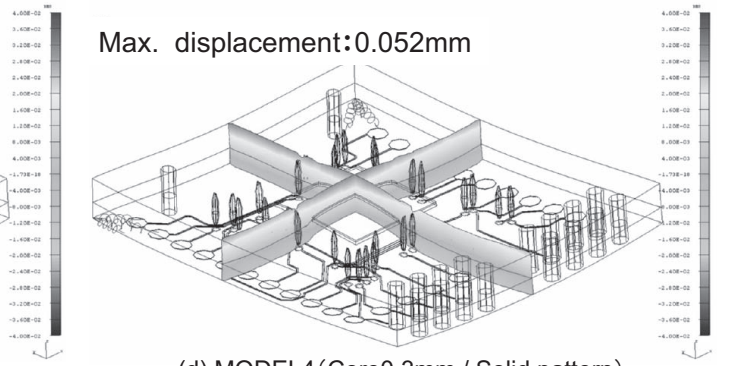

(d) MODEL4 (Core0.3mm / Solid pattern)

Fig. 7 Calculated thermal deformation

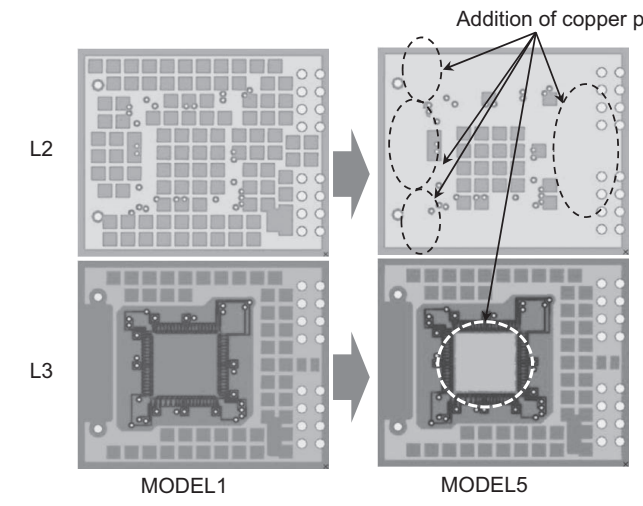

(a) Pattern modification

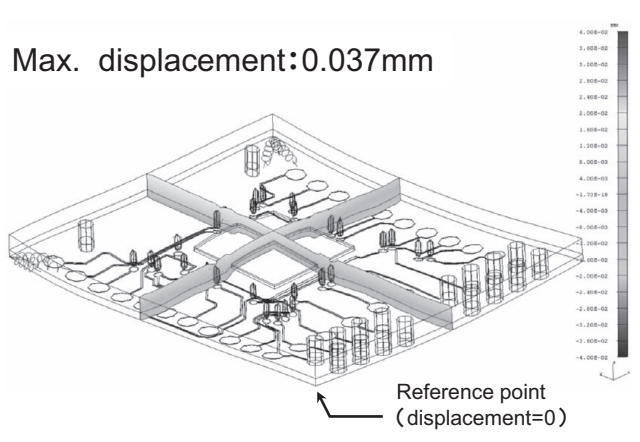

(b) Calculated thermal deformation of MODEL5

Fig. 8 Reduction of thermal deformation by pattern modification

えることが可能と予想された。以上の結果より，配線板の パターン設計を適正化することで配線板の熱変形量を制御 できる可能性が示された。

\section{6. おわりに}

部品内蔵基板のこれまでの歩みを振り返ると共に，現在 部品内蔵基板が直面する課題について考察した。本稿で述 べた課題以外にも, 内蔵部品検査を含めた最終検查技術, またそれに関連して, 内蔵された部品の保証を配線板メー カとユーザとの間でどのように線引きするかといった品質 保証契約上の課題などが存在する。

部品内蔵基板が 15 年程前に期待されたほど市場で広まっ ていない理由はこれらが絡み合い決して単純ではないが, 市場の要求自体は決して減ってはおらず，むしろ期待が高 まりつつある。さらに 3 次元形状配線への展開を考えた際
には，第 4 世代・第 5 世代と呼ぶであろう新たな部品内蔵 技術が必要とされることが予想され，この分野で日本が リードし続けることを期待したい。

(2014.5.9- 受理)

\section{文献}

1）見山克己：“ベアチップ内蔵基板の実用化事例とその実装技 術,”エレクトロニクス実装学会 EPADs 研究会 2009 年度第 3 回公開研究会, 2009

2）若林 猛：“部品内藏技術と次世代実装材料：WLP\&EWLP 技術の変遷と今後の実装技術, ”エレクトロニクス実装学会 誌, Vol. 12, No. 2, pp. 120-124, 2009

3）青山雅之, 神谷博輝：“カーナビゲーションに実用化された “部品内蔵 PALAP”を支える『基材』『回路形成』『部品搭 載\&積層』技術の連携, ”エレクトロニクス実装学会 EPADs 
研究会 2009 年度第 1 回公開研究会, 2009

4) 特開平 5-13914

5) B. Mahler and P. Schroeder: "Planar Resistors in PCB Design," Electronic Manufacturing, January 1989

6) 米国特許, 第 5155655 号

7) “平成 16 年度特許流通支援チャート 電子部品内層基板, ” 独立行政法人工業所有権情報・研修館， 2005

8）見山克己：“厚膜焼成法を用いた受動素子内蔵プリント配線 板,”マテリアルインテグレーション, Vol. 23, No. 12, pp. 29-33, 2010

9）見山克己：“ベアチップ内蔵基板の実用化事例とその実装技 術, ”第 24 回エレクトロニクス実装学会春期講演大会講演 論文集, pp. 350-351, 2010

10) 福岡義孝, 笹岡賢司, 本村知久 : “受動チップ部品/能動デ バイス混載内蔵配線板の開発と実用化, ”エレクトロニクス
実装学会誌, Vol. 11, No. 42,pp. 260-270, 2008

11）上原利久：エレクトロニクス実装学会部品内蔵技術委員会 公開研究会 2012 年度第 2 回公開研究会, 2012

12）見山克己, 高橋寿文, 岩田 智行, 田中大之 : “ベアチップ 内蔵プリント配線板の信頼性に及ぼす配線板構造の影響,” エレクトロニクス実装学会誌, Vol. 15, No. 7, pp. 550-557, 2012

著者紹介

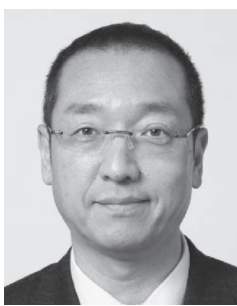

見山克己（みやま かつみ）

北海道科学大学 (旧北海道工業大学) 工学部機械 工学科教授。博士（工学），技術士（金属部門）。 1987 年北海道大学工学部卒業, 同年日本特殊陶業 株式会社入社，セラミックと金属の接合技術の開 発に従事。1998 年クローバー電子工業株式会社入 社, 高密度配線プリント配線板や部品内蔵技術の 開発に従事。2010 年北海道工業大学創生工学部機 械システム工学科准教授, 現在に至る。 